STUDIA I PRACE WYDZIAKU NAUK EKONOMICZNYCH I ZARZĄDZANIA NR 39, t. 1

DOI:10.18276/sip.2015.39/1-05

\author{
Katarzyna Koziol-Nadolna* \\ Uniwersytet Szczeciński
}

\title{
OSOBOWOŚĆ CZŁOWIEKA A SKŁONNOŚĆ DO WPROWADZANIA INNOWACJI
}

\begin{abstract}
Streszczenie
Celem artykułu jest wskazanie cech osobowości i typów osobowości kierowników i pracowników skłaniających do wprowadzania innowacji oraz przedstawienie koncepcji osobowości innowacyjnej. Artykuł ma charakter teoretyczny. Składa się z trzech części: w pierwszej przedstawiono definicję osobowości, w drugiej koncepcję osobowości innowacyjnej, natomiast część trzecia zawiera przegląd wyników badań na temat typów osobowości i cech osobowości i skłonności do wprowadzania innowacji. W artykule przybliżono czynniki wynikające $z$ indywidualnych cech danego człowieka, czyli osobowościowe, i ich związek z skłonnością do wprowadzania innowacji. Z przeglądu badań płynie wniosek, że bycie innowacyjnym wynika także z posiadania specyficznych cech osobowościowych.
\end{abstract}

Słowa kluczowe: osobowość człowieka, proces innowacyjny, osobowość innowacyjna

\section{Wprowadzenie}

Można zaobserwować zainteresowanie ekonomistów problematyką osobowości człowieka i jej oddziaływania na różne postawy, zachowania, wartości czy priorytety człowieka. Jednym z obszarów badań jest wpływ osobowości człowieka na

\footnotetext{
*Adres e-mail: kkoziol@univ.szczecin.pl.
} 
proces innowacyjny, czyli ciąg zdarzeń prowadzących do powstania i wdrożenia innowacji na rynek.

Innowacyjność jest procesem, na który oddziałuje szereg czynników: ekonomicznych, społecznych, organizacyjnych, psychologicznych czy historycznych. Uwarunkowania zmieniają się w czasie, mają charakter dynamiczny i zależą od wielu czynników. Najczęściej dzieli się je na wewnętrzne i zewnętrzne. Do czynników wewnętrznych zalicza się m.in. czynniki jednostkowe, które wynikają z indywidualnych cech osobowości danej osoby.

Można więc założyć, że stosunek pracowników czy kierowników do zachowań innowacyjnych, wprowadzania innowacji jest także wynikiem specyficznych cech ich osobowości. Posiadanie takich cech będzie skłaniało daną osobę do podejmowania określonych zachowań, w tym innowacyjnych.

\section{Definicja osobowości}

W psychologii, socjologii czy pedagogice nie występuje jedna definicja osobowości. Osobowość jest postrzegana bardzo wieloznacznie, szeroko, stąd można wskazać różne definicje osobowości i różne koncepcje osobowości. Jest to zagadnienie bardzo trudne, stwarzające problemy badawcze. J.M. Oldham i L.B. Morris definiują osobowość jako system obejmujący wszystkie charakterystyczne cechy

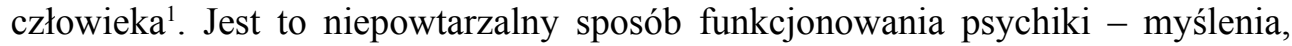
odczuwania, zachowania oraz radzenia sobie z problemami. Podstawy osobowości, czyli m.in. naturalny poziom aktywności, rozrzut nastrojów i zakres reakcji, są dziedziczne. Genetyczny aspekt osobowości określany jest jako temperament. Natomiast otoczenie, doświadczenia z okresu dzieciństwa, dorastania oraz inne kształtują ją ostatecznie.

W. Okoń osobowość definiuje jako ,zespół stałych właściwości i procesów psychofizycznych, odróżniających daną jednostkę od innych, wpływających na organizację jej zachowania, a więc na stałość w nabywaniu i porządkowaniu doświadczeń, wiadomości i sprawności, w reagowaniu emocjonalnym, w stosunkach z innymi ludźmi oraz na stałość w wyborze celów i wartości”’2.

1 J.M. Oldham, L.B. Morris, Twój psychologiczny autoportret, Czarna Owca, Warszawa 1997, s. 28 .

2 W. Okoń, Nowy stownik pedagogiczny, Żak, Warszawa 2001. 
G. Allport uważał cechy za podstawowe jednostki strukturalne osobowości. Cechy definiował jako predyspozycje do reagowania w określony sposób, „każdy wyróżniający się rys osobowości”. Predysponują one do określonych zachowań i odpowiadają za ich względną stałość w różnym czasie i odmiennych sytuacjach ${ }^{3}$.

Cechy osobowości są odpowiedzialne za sposób zachowywania się i myślenia każdego człowieka, za jego relacje i kontakty z innymi ludźmi. Zazwyczaj nie ulegają zmianie, przez co dana osoba działa i myśli podobnie w porównywalnych sytuacjach. Jeśli jednak ktoś ma pewne cechy znacznie wyostrzone, wyolbrzymione i wyraźnie odbiegające od rozpowszechnionych w danej kulturze wzorców, co utrudnia mu współżycie z innymi, narażając jego i otoczenie na cierpienie, można podejrzewać zaburzenia osobowości.

W literaturze przedmiotu znaleźć można różne koncepcje osobowości i bazujące na nich podziały koncepcji osobowości. Różnią się one między sobą opisem osobowości, jej rozwojem, czynnikami wpływającymi na zaburzenia osobowości, metodami pomocy. P.G. Zimbardo, R.L. Johnson i V. McCann wyróżniają w swojej pracy pięć teoretycznych ujęć osobowości: teorie psychodynamiczne, humanistyczne, społeczno-poznawcze, dyspozycyjne i trendy współczesne $e^{4}$.

A. Gałdowa proponuje podział koncepcji osobowości na klasyczne koncepcje osobowości (np. Z. Freuda, A. Adlera, C.G. Junga), koncepcje z okresu wielkich zmian w psychologii (np. G. Allporta, A. Maslowa) oraz współczesne ujęcia (np. A. Bandura, W. Mischel, J. Rotter, psychologia transpersonalna) ${ }^{5}$.

\section{Istota osobowości innowacyjnej}

E. Hagen w 1962 r. stworzył koncepcję osobowości innowacyjnej ${ }^{6}$. Prowadził badania, których wynikiem było określenie dwóch przeciwstawnych sobie syndromów osobowości charakterystycznych dla społeczeństwa tradycyjnego i nowoczes-

3 C.S. Hall, G. Lindzey, J.B. Campbell, Teorie osobowości, Wydawnictwo Naukowe PWN, Warszawa 2010, s. 31.

4 P.G. Zimbardo, R.L. Johnson, V. McCann, Psychology. Core Concepts, Pearson Education, Boston 2008.

5 Klasyczne i współczesne koncepcje osobowości, red. A. Gałdowa, Wydawnictwo Uniwersytetu Jagiellońskiego, Kraków 2005.

6 E. Hagen, On the Theory of Social Change, Dorsey Press, Homewood 1962; P. Sztompka, Socjologia zmian społecznych, Znak, Kraków 2005, s. 224-227; www.pi.gov.pl/ (23.02.2015). 
nego. Wytworem społeczeństwa tradycyjnego i warunkiem koniecznym dla jego trwałego funkcjonowania jest osobowość autorytarna. W wyniku upadku społeczeństwa tradycyjnego, otwarcia hierarchii klasowej, w czasie rewolucji społecznych, np. wraz z uprzemysłowieniem i urbanizacją pojawiła się osobowość innowacyjna. Jest ona warunkiem wstępnym dla wzrostu gospodarczego, rozprzestrzeniania się przedsiębiorczości i formacji kapitalistycznej.

Utrata dotychczasowego statusu prowadzi do wykształcenia się form adaptacyjnych:

- wycofania,

- rytualnego trzymania się starych wzorów,

- buntu przeciwko sytuacji nieakceptowanej,

- innowacji.

Zdaniem P. Sztompki to właśnie dwie ostatnie formy adaptacyjne wyjaśniają pojawienie się osobowości innowacyjnej. Różnice pomiędzy osobowością autorytarną a innowacyjną obrazuje tabela 1 .

Tabela 1. Osobowość autorytarna i osobowość innowacyjna

\begin{tabular}{|l|l|l|}
\hline \multicolumn{1}{|c|}{ Cecha } & \multicolumn{1}{|c|}{ Osobowość autorytarna } & \multicolumn{1}{|c|}{ Osobowość innowacyjna } \\
\hline Nastawienie do rzeczywistości & $\begin{array}{l}\text { podporządkowanie wzorom ży- } \\
\text { cia dyktowanym przez tradycję } \\
\text { i władzę, a legitymizowanym } \\
\text { przez ich rzekomo wieczna na- } \\
\text { turę i nadprzyrodzone pocho- } \\
\text { dzenia }\end{array}$ & $\begin{array}{l}\text { peławości i manipulacyj- } \\
\text { ustanne poszukiwanie ukrytych } \\
\text { prawidłowości w celu wpływa- } \\
\text { nia na zjawiska i ich kontrolo- } \\
\text { wanie }\end{array}$ \\
\hline $\begin{array}{l}\text { Postrzeganie roli jednostki } \\
\text { w świecie }\end{array}$ & $\begin{array}{l}\text { uległość, posłuszeństwo, kon- } \\
\text { formizm, unikanie odpowie- } \\
\text { dzialności i potrzeba podporząd- } \\
\text { kowania }\end{array}$ & $\begin{array}{l}\text { branie osobistej odpowiedzial- } \\
\text { ności za złe strony świata połą- } \\
\text { czone zposzukiwaniem lepszych } \\
\text { rozwiązań i próbami wprowa- } \\
\text { dzania zmian }\end{array}$ \\
\hline Styl przywództwa & $\begin{array}{l}\text { sztywność, wysokie oczeki- } \\
\text { wania i ogromne wymagania } \\
\text { względem podwładnych }\end{array}$ & $\begin{array}{l}\text { otwartość i tolerancja wobec } \\
\text { podwładnych, sprzyjanie ich } \\
\text { oryginalności i innowacyjności }\end{array}$ \\
\hline $\begin{array}{l}\text { Poziom kreatywności i innowa- } \\
\text { cyjności }\end{array}$ & $\begin{array}{l}\text { brak kreatywności i innowacyj- } \\
\text { ności }\end{array}$ & $\begin{array}{l}\text { kreatywność, wysoka ocena ory- } \\
\text { ginalności i nowości, niezaspo- } \\
\text { kojona ciekawość }\end{array}$ \\
\hline
\end{tabular}

Źródło: www.pi.gov.pl/ (23.02.2015).

Można zauważyć, że oba typy osobowości są sobie przeciwstawne we wszystkich charakteryzowanych aspektach. 


\section{Typy i cechy osobowości a skłonność do innowacji}

Badania przeprowadzone w 2011 r. przez Forbes Insights w europejskich firmach wśród 1245 kierowników pozwoliły stworzyć portret pięciu typów osobowości, z których każdy odgrywa ważną rolę w cyklu innowacyjnym, wymyślając idee, przeprowadzając je przez kanały korporacyjne, tworząc strategie oraz nadzorując ich wdrożenie i wykonanie 7 . Pracownicy z różnymi osobowościami różnią się między sobą wartościami, postawami, priorytetami, ale mozaika takich osobowości sprzyja tworzeniu innowacyjnego środowiska w przedsiębiorstwie. Najbliżej do czystej postaci ducha przedsiębiorczości i innowacyjności jest eksperymentatorom i „trzęsącym interesem".

Pierwszym wyróżnionym typem osobowości jest „trzęsący interesem” (Movers \& Shakers). Są to osoby przedsiębiorcze, które są w cyklu innowacji liderami. Według szacunków stanowią 22\% wszystkich kierowników. Charakteryzują się umiejętnością wpływania na innych, lubią wychylać się przed szereg, promować nowe projekty, rozdzielać zadania w procesie. Motywują ich aspekty materialne, ale najważniejszą zachętą jest możliwość tworzenia dziedzictwa dla przyszłych pokoleń.

Drugim typem są kontrolerzy (Controllers), którzy stanowią ok. 15\% wszystkich kierowników. Jest to praktyczny typ osobowości, który nie lubi ryzyka i unika niejasnych projektów. Skupiają się na konkretnych, sprecyzowanych zadaniach, dzięki czemu łatwiej im kontrolować to, co dzieje się dookoła nich. Potrafią organizować ludzi i mobilizować ich do działania Często są właścicielami firm, którzy na swojej osobowości zbudowali całe przedsiębiorstwo. Nie są dobrymi graczami zespołowymi, wolą pracować w odosobnieniu.

Osobowość typu kotwica (Hangers-On) jest reprezentowana przez ok. 23\% kierowników. Pełnią ważną rolę w grupie, przypominając jej o ograniczeniach (prawnych, finansowych itp.) oraz procesach instytucjonalnych. Ich głównym zadaniem w procesie innowacji jest ściąganie na ziemię marzycieli i fantastów. Podobnie jak kontrolerzy nie przepadają za niepewnym środowiskiem pracy, przedkładają konwencjonalny sposób myślenia i wypróbowane rozwiązania nad nowe i niesprawdzone.

7 Nurturing Europe's Spirit of Enterprise: How Entrepreneurial Executives Mobilize Organizations to Innovate, Forbes Insights, December 2011, www.forbes.com/forbesinsights/europe_entrepreneurs/index.html\#sthash.hP5sYUNC.dpuf (22.02.2015); www.coslychacwbiznesie.pl/ludzie/raz-dwatrzy-innowatorem-jestes-ty (22.02.2015). 
Czwartym typem osobowości są gwiazdy - pupile (Star Pupils) w procesie innowacyjnym. Umieją znaleźć talenty wśród współpracowników, odpowiednich mentorów czy innowacyjne pomysły. Dobrze budują własny wizerunek, łatwo pną się po szczeblach kariery. $24 \%$ osób na stanowiskach kierowniczych to pupile.

Eksperymentatorzy (Experimenters) są wytrwali i otwarci na nowe rzeczy, skłonni do ryzyka, doskonali w przeprowadzaniu pomysłów przez różne fazy rozwoju i wykonania. Ich wytrwałość jest szczególnie ważna w cyklu innowacyjnym zwłaszcza wtedy, gdy na drodze pojawiają się kłopoty. Lubią dzielić się swoim doświadczeniem i wiedzą z innymi. Są perfekcjonistami z tendencją do pracoholizmu. Około 16\% kierowników to eksperymentatorzy.

W literaturze przedmiotu są dostępne wyniki badań na temat cech pracowników i skłonności do inicjacji i wprowadzania innowacji. Badania M. Juchniewicz i B. Grzybowskiej przeprowadzone w mikroprzedsiębiorstwach ${ }^{8}$ na temat m.in. znaczenia cech pracowników wpływających na powstawanie i wdrażanie innowacji pokazały, że zdecydowanie najważniejszą cechą mającą wpływ na powstawanie innowacji jest wiedza, którą pracownicy nabywają w wyniku doświadczenia zawodowego. Aż 79\% badanych oceniło ją jako ważną. Zdaniem autorek taki rodzaj wiedzy jest bezpośrednio związany z wykonywaną pracą, sprzyja procesom kreowania nowych, innowacyjnych rozwiązań, które są efektem posiadanych umiejętności. Jeżeli wiedzy i umiejętnościom towarzyszy chęć i motywacja ich wykorzystania do stworzenia takich rozwiązań, to oznacza proinnowacyjne nastawienie pracowników w firmie i prawdopodobnie sprzyjający klimat do takiego zaangażowania.

Umiejętność współpracy oraz wytrwałość i upór w dążeniu do celu były następnymi ważnymi cechami mającymi wpływ na umiejętności pracowników w zakresie tworzenia innowacji w ocenie odpowiednio $74 \%$ i prawie $70 \%$ badanych. $66 \%$ badanych wskazało na umiejętność radzenia sobie w sytuacjach stresowych, a 58\% na umiejętność pogodzenia się z niepowodzeniami jako ważne cechy pracownika.

W przypadku cech pracowników mających znaczenie i wpływ na wdrożenie innowacji na pierwszym miejscu respondenci wskazali wiedzę fachową (75\% respondentów). Kolejno wymieniali:

- upór, konsekwencję i cierpliwość,

- zdolności komunikacyjne,

8 M. Juchniewicz, B. Grzybowska, Innowacyjność mikroprzedsiębiorstw w Polsce, PARP, Warszawa 2010, s. 111-113. 
- silną motywację do osiągnięć,

- zdolności do pracy zespołowej,

- kreatywność rozumianą jako zdolność do tworzenia wielu rozwiązań,

- inicjatywę - chwytanie okazji lub ich tworzenie,

- inspirowanie i wywieranie wpływu na innych,

- doświadczenia we wdrażaniu innowacyjnych pomysłów,

- umiejętność przenoszenia innowacyjnych pomysłów z innych dziedzin.

Badania psychologów zajmujących się twórczością wykazały, że mimo istniejących różnic indywidualnych między twórcami można wyróżnić następujące cechy osobowości pojawiające się u większości jednostek twórczych":

a) otwartość umysłu, czyli tolerancję na informacje niepewne, sprzeczne, dziwne, która nie polega na ich bezkrytycznej akceptacji, lecz na ich uważnym rozpatrywaniu;

b) silną motywację wewnętrzną charakteryzującą się wytrwałością i uporem w rozwiązywaniu problemów; głównym motywem pracy twórców jest ciekawość poznawcza i zadowolenie związane z rozwiązywaniem problemów, natomiast mniejsze znaczenie ma gratyfikacja materialna;

c) niezależność w myśleniu i działaniu; ludzie twórczy są nonkonformistami, postępują zgodnie z własnymi przekonaniami, tym samym trudniej ulegają naciskowi grupy, w której funkcjonują;

d) pozytywny stosunek do siebie oraz poczucie własnej wartości i godności;

e) preferencję umiarkowanego ryzyka;

f) umiarkowany krytycyzm, czyli umiejętność dokonania krytycznej oceny stanu wiedzy naukowej, dużą ostrożność w przyjmowaniu nowych hipotez i teorii, nieuleganie presji mody i reklamy;

g) poczucie przeznaczenia, sensu i wartości dotyczącej swojej pracy;

h) szerokie zainteresowania innymi niż zawodowe dziedzinami wiedzy.

Na proces innowacyjny wpływają, jak już wspominano, różne czynniki-oprócz osobowościowych także ekonomiczne, społeczne czy prawne. Kolejne ciekawe wyniki badań dotyczące czynników wpływających na innowacyjność pracowników

9 J. Kozielecki, Koncepcje psychologiczne człowieka, Państwowy Instytut Wydawniczy, Warszawa 1976; S. Popek, Człowiek jednostka twórcza, Wydawnictwo Uniwersytetu Marii Curie-Skłodowskiej, Lublin 2001; J. Sołowa, Psychologia twórczości, GWP, Gdańsk 1997, za: R. Drozdowski, A. Zakrzewska, K. Puchalska, M. Morchat, D. Mroczkowska, Wspieranie postaw proinnowacyjnych przez wzmacnianie kreatywności jednostki, PARP, Warszawa 2010. 
przeprowadzili M.H. Hammond i współpracownicy ${ }^{10}$, którzy rozpatrywali je na wszystkich etapach procesu innowacyjnego: od momentu formowania się pomysłów do ich wdrożenia. Czynniki zostały podzielone na cztery grupy: różnice indywidualne, motywacja, właściwości pracy oraz kontekst pracy. Do różnic indywidualnych uwzględnionych w analizach zaliczono cechy osobowościowe, takie jak osobowość kreatywna i otwartość na doświadczenie, a także zmienne demograficzne: poziom wykształcenia i staż pracy. Motywację podzielono na motywację wewnętrzną, której celem nie jest osiągnięcie zewnętrznych nagród, a aktywność jest celem sama w sobie. Motywacja zewnętrzna zachodzi natomiast wówczas, kiedy pracownik angażuje się wskutek zewnętrznych nacisków albo dla wewnętrznych korzyści.

Właściwości pracy analizowane przez badaczy to złożoność pracy, autonomia pracowników oraz postrzeganie swojej roli zawodowej jako wymagającej kreatywności i innowacyjności. Do zmiennych kontekstualnych zaliczono m.in. organizacyjny klimat dla kreatywności i innowacyjności, zasoby organizacyjne, postrzegane wsparcie przełożonych, jakość relacji między przełożonymi a podwładnymi czy transformacyjny styl przywództwa.

Analiza wykazała, że zmienne osobowościowe były istotnie związane z innowacyjnością, ale związki te były słabe. Zarówno osobowość kreatywna, jak i otwartość na doświadczenie wiązały się z większą innowacyjnością, natomiast czynniki demograficzne nie wiązały się z większą bądź mniejszą innowacyjnością. Motywacje wewnętrzna i zewnętrzna pracownika wiązały się także $\mathrm{z}$ większą innowacyjnością.

Najsilniej jednak ze wszystkich analizowanych kategorii okazały się te związane z poziomem innowacyjności właściwości pracy: im większa złożoność pracy, większa autonomia i większe oczekiwania co do kreatywności i innowacyjności charakteryzowały środowisko pracy, tym większa była innowacyjność pracowników.

Czynniki z ostatniej badanej kategorii - kontekstu pracy - także okazały się być silnie związane z innowacyjnością pracowników, najsilniejszym predyktorem innowacyjności $\mathrm{w}$ analizowanych badaniach było wsparcie przełożonych oraz jakość relacji między przełożonymi a podwładnymi.

10 M.H. Hammond, N.L. Neff, J.L. Farr, A.R. Schwall, X. Zhao, Predictors of Individual-Level Innovation at Work: A Meta-Analysis, „Psychology of Aesthetics, Creativity, and the Arts” 2011, No. 1, s. 90-105, za: Z. Mockałło, Innowacyjność pracowników w kontekście psychospołecznych czynników środowiska pracy, „Bezpieczeństwo Pracy” 2012, nr 9, s. 9-10. 
Wyniki te pokazują, że innowacyjność organizacji zależy od wielu czynników; okazało się że najważniejsze są warunki pracy i relacje między podwładnymi i przełożonymi, a mniejsze znaczenie odgrywają cechy osobowościowe.

\section{Podsumowanie}

Nasilenie procesów innowacyjnych w przedsiębiorstwie jest wypadkową wielu uwarunkowań, mogą mieć, jak wspominano, naturę ekonomiczną, organizacyjną, socjologiczną, psychologiczną, filozoficzną bądź historyczną. W artykule spróbowano przybliżyć czynniki wynikające z indywidualnych cech danego człowieka, czyli osobowościowe, i ich związek z skłonnością do wprowadzania innowacji. Z przeglądu badań płynie wniosek, że bycie innowacyjnym wynika także z posiadania specyficznych cech osobowościowych. Dysponowanie takimi cechami będzie skłaniało pracownika czy kierownika do podejmowania zachowań innowacyjnych: tworzenia i wdrażania innowacji.

Oznaczać to może, że innowacyjność jest cechą osobowości człowieka, na którą składają się względnie trwałe cechy jak np. kreatywność, otwartość na doświadczenie, upór, konsekwencja, silna motywacja skłaniająca do zachowań innowacyjnych.

Badania dotyczące typów osobowości i skłonności do wprowadzania innowacji wykazały, że najbliżej do czystej postaci ducha przedsiębiorczości i innowacyjności jest dwóm typom osobowości: eksperymentatorom i „trzęsącym interesem”.

Należy cały czas jednak mieć świadomość, że proces innowacyjny jest wypadkową bardzo wielu czynników - osobowość jest czynnikiem stymulującym, ale jednym $\mathrm{z}$ wielu.

\section{Literatura}

Drozdowski R., Zakrzewska A., Puchalska K., Morchat M., Mroczkowska D., Wspieranie postaw proinnowacyjnych przez wzmacnianie kreatywności jednostki, PARP, Warszawa 2010. Hagen E., On the Theory of Social Change, Dorsey Press, Homewood 1962.

Hall C.S., Lindzey G., Campbell J.B., Teorie osobowości, Wydawnictwo Naukowe PWN, Warszawa 2010.

Juchniewicz M., Grzybowska B., Innowacyjność mikroprzedsiębiorstw w Polsce, PARP, Warszawa 2010. 
Klasyczne i współczesne koncepcje osobowości, red. A. Gałdowa, Wydawnictwo Uniwersytetu Jagiellońskiego, Kraków 2005.

Kozielecki J., Koncepcje psychologiczne człowieka, Państwowy Instytut Wydawniczy, Warszawa 1976.

Mockałło Z., Innowacyjność pracowników w kontekście psychospołecznych czynników środowiska pracy, „Bezpieczeństwo Pracy” 2012, nr 9.

Nurturing Europe's Spirit of Enterprise: How Entrepreneurial Executives Mobilize Organizations to Innovate, Forbes Insights, December 2011, www.forbes.com/forbesinsights/ europe_entrepreneurs/index.html\#sthash.hP5sYUNC.dpuf (22.02.2015).

Okoń W., Nowy słownik pedagogiczny, Żak, Warszawa 2001.

Oldham J.M., Morris L.B., Twój psychologiczny autoportret, Czarna Owca, Warszawa 1997.

Popek S., Człowiek jednostka twórcza, Wydawnictwo Uniwersytetu Marii Curie-Skłodowskiej, Lublin 2001.

Sztompka P., Socjologia zmian społecznych, Znak, Kraków 2005.

www.coslychacwbiznesie.pl/ludzie/raz-dwa-trzy-innowatorem-jestes-ty (22.02.2015). www.pi.gov.pl/ (23.02.2015).

Zimbardo P.G., Johnson R.L., McCann V., Psychology. Core Concepts, Pearson Education, Boston 2008.

\title{
HUMAN PERSONALITY AND PROPENSITY TO INNOVATE
}

\begin{abstract}
This article aims to identify personality traits and personality types of workers tending to innovate. Article is a theoretical, consists of three parts, the first presents the definition of personality, the essence of innovative personality in the second, while the third part provides an overview of the results of research on personality types and traits of personality and willingness to innovate. The article brought closer factors resulting from the individual characteristics of the man, that personality and their relationship with the propensity to innovate. A review of studies is the conclusion that being innovative is also due to hold specific personality traits.
\end{abstract}

Translated by Katarzyna Koziol-Nadolna

Keywords: human personality, innovation process, innovative personality

JEL Code: O3 